\title{
In vivo and in vitro outcomes of alumina, zirconia and their composited ceramic-on-ceramic hip joints
}

\author{
Herman Shah Abd RAHMAN, ${ }^{\dagger}$ Dipankar CHOUDHURY, Noor Azuan Abu OSMAN, \\ Hanie Nadia SHASMIN and Wan Abu Bakar Wan ABAS \\ Department of Biomedical Engineering, Faculty of Engineering, University Malaya, Kuala Lumpur, Malaysia
}

\begin{abstract}
Despite of brittleness, Ceramic-on-Ceramic (CoC) hip joints are appealing to arthritic patients because of its low friction rate, high wear resistance and low risk of osteolysis. The objectives of the study were to review and summarize the performance of Alumina, Zirconia and their functional graded material (FGM) for artificial hip joints in vivo and vitro outcomes. The Method of the study was scoping review which focused on the peer reviewed journals containing with alumina, zirconia and alumina zirconia FGM to CoC hip prosthesis. Advanced version of Alumina CoC was found to have excellent hardness but low fracture toughness. Alumina $\mathrm{CoC}$ hip joints was found to have a revision rate as high as $5 \%$ after 20 clinical outcomes. Zirconia ceramic had high fracture toughness but relatively low hardness when compared to Alumina ceramic. Alumina-Zirconia FGM consists both high hardness (outer surface) and improved fracture toughness (inner core) which led to better mechanical and tribological properties. However, to date, there is still no literature was found to have long period of clinical outcomes. No article was screened carrying out durability study of Alumina/Zirconia FGM for CoC hip joints with appropriate tribological experiment. Alumina/ Zirconia FGM could be very effective for long term durability of $\mathrm{CoC}$ hip joints. Nevertheless, this FGM needs to be investigated under appropriate tribological tests considering dynamic loadings, dimension and shape of the joints, lubricant similar to synovial fluid and large number of cycles. The long term clinical outcomes also need to be published to increase its acceptability to young active patients.
\end{abstract}

(C2013 The Ceramic Society of Japan. All rights reserved.

Key-words : Alumina, Zirconia, Alumina-zirconia composite, Total hip replacement

[Received September 12, 2012; Accepted October 29, 2012]

\section{Introduction}

Total hip replacement (THR) is one of the successful surgical methods to relief pain and stabilise the mobility with approximately one million hip replacement are performed worldwide annually. ${ }^{1)}$ With over 5 million components implanted worldwide ${ }^{2)}$ ceramic-on-ceramic $(\mathrm{CoC})$ hip replacement has attracted the attention of biomedical scientist, orthopaedic surgeons and arthroplasty patients due to its excellent bio-tribological properties likewise low wear, low friction rate and high scratch resistance. These properties make the $\mathrm{CoC}$ hip joint as a good alternative as compared to metal-on-metal and metal-on-polyethylene articulations. However, its long term post clinical results have not been published yet, whereas the brittleness of ceramic is still a concern. Currently, no bearing couples has demonstrated perfect for THR as yet. Since the first experience with CoC THR reported by Boutin in 1971, ${ }^{3)}$ there were several stages performed on CoC hip joints to improve the fracture toughness thus increase its acceptability among surgeons and patients. Most of the refined $\mathrm{CoC}$ joints were either Alumina $\left(\mathrm{Al}_{2} \mathrm{O}_{3}\right)$ or Zirconium dioxide $\left(\mathrm{ZrO}_{2}\right)$ or Alumina and Zirconia composite based. The objective of this review study was to assess Alumina, Zirconia and Alumina-Zirconia composited material for implanted joints in the following terms: 1) identifying the weakness and strength points of the available Alumina-Zirconia composite on tribological properties; 2) summarizing the vivo and vitro outcomes of Alumina, Zirconia and Alumina-Zirconia composite for THR;

Corresponding author: H. S. A. Rahman; E-mail: herman.shah@ um.edu.my and 3) recommending improvement and development of Alumina-Zirconia composite material for CoC hip joints.

\section{Methodology}

The following keywords were used in the Science Direct, Google Scholars, and PubMed; Alumina, Zirconia, AluminaZirconia composite, hip joint implant, prothesis, clinical outcomes, vitro and vivo outcomes of Alumina-Zirconia composited material for total hip joints, tribology of Alumina-Zirconia composited material for total hip joints.

Selection criteria: Only Peer-reviewed journal papers were selected. Experimental, clinical outcomes studies were of interest for this paper and, as such, subjective studies that were completed via the use of questionnaires and finite element study designs were excluded. The study design, method of subject selection, research tools, protocol and outcome parameters were reviewed. Approximately more than a hundred of peer review papers were found in these sources and fifty most relevant papers were selected based on Alumina, Zirconia and Alumina-Zirconia composited material for hip joint prosthesis. The outcomes of the results were presented in three main aspects: Aluminum oxide $\left(\mathrm{Al}_{2} \mathrm{O}_{3}\right)$ CoC hip joints; Zirconia $\left(\mathrm{ZrO}_{2}\right) \mathrm{CoC}$ hip joints; and Alumina-Zirconia composited material also known as Zirconia targeted Alumina based hip prosthesis.

\section{Results}

\subsection{Alumina ceramic}

Aluminum oxide $\left(\mathrm{Al}_{2} \mathrm{O}_{3}\right)$ ceramics has been recognized as favorable bearing surface because of its superior mechanical properties and excellent bio-competitive nature. $\mathrm{Al}_{2} \mathrm{O}_{3}$ is a very 
Table 1. Progression of alumina $\left(\mathrm{Al}_{2} \mathrm{O}_{3}\right)$ mechanical properties in the last four decades ${ }^{2), 4), 5)}$

\begin{tabular}{|c|c|c|c|c|}
\hline & $1970 \mathrm{~s}$ & $1980 \mathrm{~s}$ & $1990 \mathrm{~s}$ & $2000 \mathrm{~s}$ \\
\hline Strength (min.), $\mathrm{MPa}$ & 400 & 500 & 580 & 631 \\
\hline Mean grain size $(\mu \mathrm{m})$ & $<7$ & $<3.2$ & 1.5 & $<1.5$ \\
\hline Hardness $(\mathrm{VH})^{*}$ & 1800 & 1900 & 2000 & 2000 \\
\hline 4-point bending strength (MPa) & $>400$ & $>450$ & $>500$ & $>1000$ \\
\hline Contact angle $\left(^{\circ}\right)$ & $<50$ & $<50$ & $<50$ & $<50$ \\
\hline Density $\left(\mathrm{g} / \mathrm{cm}^{3}\right)$ & 3.86 & 3.94 & 3.96 & 4.37 \\
\hline
\end{tabular}

*VH, Vickers Hardness.

hard material (more than 2000 Vickers Hardness) along with a high Young's Modulus of $380 \mathrm{GPa}$; nearly double of that Stainless Steel. ${ }^{4)}$ It is highly resistant to corrosion, abrasion, and third body wear. Moreover, ceramic contains hydrophilic property which allows better wettability of the surface to reduce wear progression. Biocompatibility test had shown that alumina is safe and has corrosion resistance with a low friction coefficient. ${ }^{5)}$ However, the early results obtained from Alumina-on-Alumina hip prosthesis were not impressive since this hip prosthesis was found to have high rate in aseptic loosing and fractures. ${ }^{6), 7)}$ The brittleness of $\mathrm{Al}_{2} \mathrm{O}_{3}$ was considered to be the main cause of the failures. However, by improving metallurgical properties which included finer grain size and higher purity, the bending strength of $\mathrm{Al}_{2} \mathrm{O}_{3}$ had increased and thus percentage of failures had reduced significantly over last 40 years. ${ }^{8)}$ The main properties of $\mathrm{Al}_{2} \mathrm{O}_{3}$ and their evolution over the time are shown in Table 1.

There was a significant improvement in $\mathrm{Al}_{2} \mathrm{O}_{3}$ manufacturing process which involved different phases of process that includes Hot Isostatic Pressing (HIP), ${ }^{4)}$ laser etching, ${ }^{9)}$ and Proofs Tests. ${ }^{10)}$ The HIPed $\mathrm{Al}_{2} \mathrm{O}_{3}$ hip prosthesis reduces the residual stresses within grain particles and this improved density and reduced grain size which producing the optimal material strength. It is compulsory for each component to undergo batch stamping with respect to identification. The application of laser etching with only $6 \mu \mathrm{m}$ depth and excellent readability rather than mechanical engraving using diamond with $300 \mu \mathrm{m}$ depth have made possible to prevent surface tension from any edge cracks. Finally, in order to ensure the quality assurance, proof testing of all parts that consists in the application of hydraulic pressure that induced a stress next to the maximum load bearing capacity. Thus, the imperfect components can be removed before final inspection. However, the fracture tendency of $\mathrm{Al}_{2} \mathrm{O}_{3}$ hip prosthesis is still becomes a big concern to orthopaedic surgeons, manufacturers and researchers. ${ }^{6), 11-13)}$ For example, Toni et al. ${ }^{8)}$ pointed out about poor bending strength of $\mathrm{Al}_{2} \mathrm{O}_{3}$ and its associated break or fracture rate. Normally, the mode of fracture related with the crack propagation phenomenon. Propagation of the crack through the Alumina structures at a different velocity based on the applied load and flaws in the materials such as porosity, scratches or the appearance of other imperfection on its surface or in the material.

\subsection{Alumina-on-alumina hip prosthesis}

Alumina $\mathrm{CoC}$ hip prosthesis is currently used for the arthritic patients since the last three decades. The experimental and retrieval data showed that early generation of $\mathrm{Al}_{2} \mathrm{O}_{3}$ hip prostheses (1974-1988) were found to have excellent biomechanical and biocompatible properties, along with good wear resistances. $^{4), 5)}$ However, its clinical outcomes were devastating due to increased ceramic component loosening ${ }^{8)}$ and high rate of fracture. ${ }^{9)}$ This revolutionary phase of Alumina (Table 2) led ortho-
Table 2. Alumina ceramics in orthopaedics-the pioneers ${ }^{14)}$

\begin{tabular}{lcc}
\hline Pioneer & Year & Proprietary's name \\
\hline Boutin & 1970 & Ceraver \\
Langer & 1971 & Keramed \\
Heimke & 1972 & Frialit \\
Griess & 1973 & - \\
Dorre & 1973 & Feldmühle \\
Semlitsch & 1977 & - \\
Willert & 1978 & - \\
Mittelmeier & 1979 & Mittelmeier \\
Osborn & 1979 & - \\
Gruner & 1980 & - \\
\hline
\end{tabular}

paedic surgeons to step aside from using the Alumina-onAlumina hip prostheses for the moment.

To overcome the high loosening and fracture rate, the second generation of $\mathrm{Al}_{2} \mathrm{O}_{3}$ hip prosthesis was developed by a German company, Biolox Forte (CeramTec, Plochingen, Germany) in 1988. The results showed that the rates of fracture were reduced to less than 5\%, after adding a small amount of metal oxide such as Calcium Oxide $(\mathrm{CaO})$ to the $\mathrm{Al}_{2} \mathrm{O}_{3}$ which produced smaller grain sizes. ${ }^{8)}$ Further improvement was achieved by the third generation of $\mathrm{Al}_{2} \mathrm{O}_{3}$ (1994-present) by applying laser etching, hot isostatic pressing and hydraulic pressure proof testing which produced a highly pure and fully dense ceramic. ${ }^{8)}$ These enhancements had dramatically reduced the rates of fracture to where several studies had recorded as low as 0.54 to $0.0 \%{ }^{15}$ ) For example, Alumina Matrix Composite (AMC) or Alumina-Zirconia composite is the newest generation (2000-present) of Alumina ceramics which is a combination of the reinforcement mechanisms of ceramics with its excellent tribological qualities. The advantage of this newest generation of ceramics is that it is twice as strong, harder, and has better wear-resistant compared with its predecessor. ${ }^{2)}$ Although a long term clinical outcomes (more than 30 years) of AMC THR bearings are not available yet, with 6-year follow up and more than 100,000 components implanted, the results are very promising as there is no complications have yet been reported. ${ }^{2}$ ) Table 3 shows clinical outcomes of Alumina $\mathrm{CoC}$ hip prostheses. It is noted that the maximum follow up period was done by Petsatodis et al. (2010) study and the revision rate was high (5.5\%).

From the table, it is known that the revision rate of Alumina $\mathrm{CoC}$ hip joints will require further investigation as the joints are expected to perform more than 30 years with very low revision rate.

\subsection{Zirconia ceramic}

Zirconia $\left(\mathrm{ZrO}_{2}\right)$ is another ceramic material which was introduced in ceramic-on-ceramic hip prosthesis in the mid1980s to overcome the limitations of the first generation Alumina prosthesis. Zirconia is a biocompatible material following to no adverse response after the insertion of $\mathrm{ZrO}_{2}$ samples into muscle or bone. ${ }^{20), 21)}$ In vitro experimentation both by Covacci et al. and Silva et al. had showed absence of mutations ${ }^{22), 23)}$ and it is also not cytotoxic. ${ }^{24)-26)}$ The mechanical properties of Zirconia are similar to Stainless Steel. Its resistance to tensile and compression resistance are about $900-1200 \mathrm{MPa}$ and $2000 \mathrm{MPa}$ respectively. ${ }^{22)}$ This material are also tolerated well the cyclical stresses. ${ }^{27)}$ Apart of this, the flexural strength of Zirconia has been known to be more than $1500 \mathrm{MPa}$ which is three times stronger than Alumina. ${ }^{28)-30)}$ However, pure Zirconia is in unstable (monoclinic) phase. Whenever a stress occurs on a Zirconia surface, the phase changes (tetragonal to monoclinic phase) 
Table 3. Clinical outcomes of alumina CoC hip prosthesis

\begin{tabular}{|c|c|c|c|c|}
\hline Authors & No. of Study & Materials & $\begin{array}{l}\text { Follow-up } \\
\text { Period }\end{array}$ & Results \\
\hline $\begin{array}{l}\text { Boyer et al., } \\
2010^{16)}\end{array}$ & $\begin{array}{c}77 \text { to } 87 \\
\text { young patients }\end{array}$ & $\begin{array}{c}32 \mathrm{~mm} \text { diameter of } \\
\text { Alumina CoC implants }\end{array}$ & $7-15$ years & $\begin{array}{l}\text { - One (1) ceramic insert broke. } \\
\text { - Aseptic loosening, the criterion for failure, the } 12 \text {-year } \\
\text { survival rate was } 91 \pm 11 \% \text { for the Cerafit trellis }{ }^{\mathrm{TM}} \\
\text { acetabular components and } 91 \pm 16 \% \text { for the } \\
\text { cemented Osteal }{ }^{\mathrm{TM}} \text { stems. } \\
\text { - The } 10 \text {-year survival rate of the entire series was } 92 \% \pm \\
11 \% \text { which including all revisions for any cause. }\end{array}$ \\
\hline $\begin{array}{l}\text { Bascarevic et al., } \\
2010^{17)}\end{array}$ & $\begin{array}{l}78 \text { to } 82 \\
\text { patients }\end{array}$ & $\begin{array}{l}28 \mathrm{~mm} \text { diameter of } \\
\text { Alumina CoC implants }\end{array}$ & $3-5$ years & $\begin{array}{l}\text { - During the follow-up period, } 51 \pm 8 \text { Alumina-on-Alumina } \\
\text { were statistically found to have no significant changes in } \\
\text { clinical and radiographic parameters. } \\
\text { - There was no ceramic breakage and no need for revision } \\
\text { surgery due to the ceramic liner. }\end{array}$ \\
\hline $\begin{array}{l}\text { Choi et al., } \\
2010^{18)}\end{array}$ & $\begin{array}{l}64 \text { to } 93 \\
\text { patients younger } \\
\text { than } 45 \text { years old }\end{array}$ & $\begin{array}{c}\text { Alumina CoC cementless } \\
\text { implants }\end{array}$ & 10-13 years & $\begin{array}{l}\text { - Two of } 93 \text { hips (2\%) had squeaking problem. One hip } \\
(1 \%) \text { was dislocated seven days after the operation. } \\
\text { - No hip had aseptic loosening of any acetabular or femoral } \\
\text { component. } \\
\text { - Neither acetabular nor femoral osteolysis was observed in } \\
\text { any hip using Alumina CoC THRs. }\end{array}$ \\
\hline $\begin{array}{l}\text { Petsatodis et al., } \\
2010^{19)}\end{array}$ & $\begin{array}{c}100 \text { to } 100 \\
\text { patient older } \\
\text { than } 60 \text { years old }\end{array}$ & $\begin{array}{l}\text { Alumina CoC cementless } \\
\text { Autophor } 900-\mathrm{S} \text { prostheses }\end{array}$ & $\begin{array}{l}\text { Average of } \\
20.8 \text { years }\end{array}$ & $\begin{array}{l}\text { - Six hips (six acetabular cups and one femoral stem) in six } \\
\text { patients underwent revision. } \\
\text { - At the time of final follow-up, the result was excellent in } \\
68 \% \text { of the hips, good in } 19 \% \text {, fair in } 9 \% \text {, and poor in } \\
4 \% \text { (according to the Merle d'Aubign'e-Postel scale) }\end{array}$ \\
\hline $\begin{array}{l}\text { Murphy et al., } \\
2006^{11)}\end{array}$ & $\begin{array}{l}194 \text { in } 173 \\
\text { patients }\end{array}$ & Alumina $\mathrm{CoC}$ & $2-9$ years & $\begin{array}{l}\text { - Bearing survival was } 97.1 \%(\mathrm{CI}, 92.3-100) \text {. } \\
\text { - One cup failed to osseointegrate; one liner was malseated } \\
\text { during the index operation; third complication was a liner } \\
\text { fracture which occurred in a multiply operated patient with } \\
\text { a trochanteric non-union. }\end{array}$ \\
\hline
\end{tabular}

resulting in net volumetric expansion in the ceramic grains that may places the bearing surface into a residual compressive stress field and thus led to detrimental properties of the material considerably. ${ }^{31)}$ In order to retain tetragonal structure, a stabilising oxide such as Magnesium-oxide $(\mathrm{MgO})$, Cerium-oxide $\left(\mathrm{CeO}_{2}\right)$ or Yttrium-oxide $\left(\mathrm{Y}_{2} \mathrm{O}_{3}\right)$ is added during the presintering stage. This crystalline adjustment is followed by an expansion that seals the crack. ${ }^{32)}$ The amount of $\mathrm{Y}_{2} \mathrm{O}_{3}$ has a reflective effect on tetragonalmonoclinic transformation. A few studies reported that by adding $\mathrm{Y}_{2} \mathrm{O}_{3}$ contents of 2 to $5 \mathrm{~mol} \%$ to TZP, the Y-TZP showed to be more unaffected by the tetragonal-monoclinic phase transformation $^{33), 34)}$ and in a study by Winnubst and Burggraaf, they found that the optimum level of $\mathrm{Y}_{2} \mathrm{O}_{3}$ for tetragonal phase retention was $3.5 \mathrm{~mol} \%{ }^{35)}$ as shown in Fig. 1.

\subsection{Zirconia-on-zirconia hip prosthesis}

Zirconia has been accepted for biomedical implants from as early as 1969 and from 1985 onwards, and Yttria stabilized Tetragonal Zirconia Polycrystal (Y-TZP) has been used widely for the Zirconia balls in THR. ${ }^{36)}$ There are a few companies that have manufactured Zirconia THR worldwide such as Norton Desmarquest Inc. (France), Morgan Matroc Inc. (UK), Kyocera and Kobelco corporations (Japan). The wear rates recorded in hip joint simulator for several bearing couples shows that zirconia-onzirconia has the least amount of volumetric wear rates $(0.016$ $\mathrm{mm}^{3} /$ million cycles) than alumina-on-alumina $\left(0.1 \mathrm{~mm}^{3} /\right.$ million cycles), alumina-on-polyethylene $\left(0.18 \mathrm{~mm}^{3} /\right.$ million cycles $)$ and zirconia-on-polyethylene $\left(14 \mathrm{~mm}^{3} /\right.$ million cycles $)$ paired bearings. ${ }^{37)}$ The Y-TZP implant ceramics have been studied extensively in this regard for its "transformation toughening" effect which explain the higher resistance of zirconia to shock and

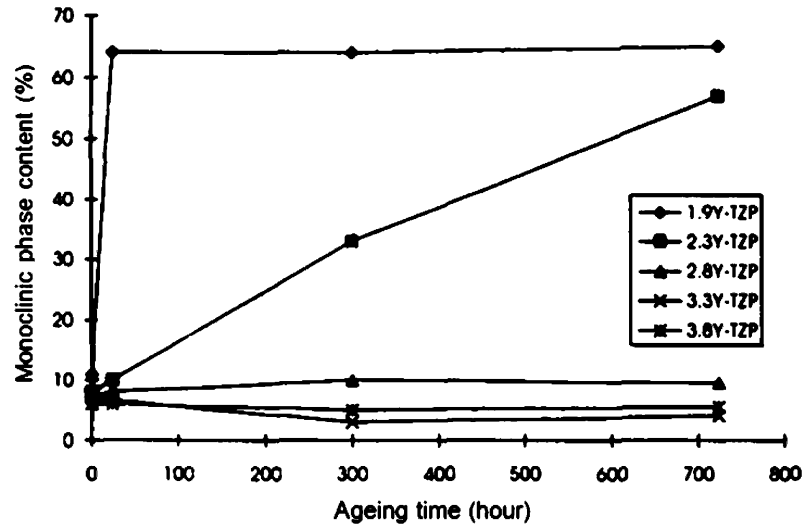

Fig. 1. Monoclinic phase transformation after different of $\mathrm{Y}_{2} \mathrm{O}_{3}$ (mol.\%) contents for TZPs aged in air at $300^{\circ} \mathrm{C} .^{33}$ )

is known to be stable under normal body conditions. ${ }^{27), 38), 39)}$ Although the transformation toughening effect in Y-TZP is very useful but its machinability is not well tolerable in terms of long lasting load bearing articulation. ${ }^{40)}$ Y-TZP is known to have an ageing effect after exposing to water molecules ${ }^{41)}$ at low temperature within the temperature range $65-500^{\circ} \mathrm{C},{ }^{42)}$ with the maximum rate of monoclinic transformation happened at $\approx 250^{\circ} \mathrm{C},{ }^{35}$ ) as shown in Fig. 2. This behavior can lead to degradation effect on its properties, the cause for the transformation of metastable Y-TZP into the monoclinic phase Y-TZP. The femoral head may also undergo degradation after several years implantation in the human body ${ }^{36)}$ and it is not certain whether it will remain in the market. 


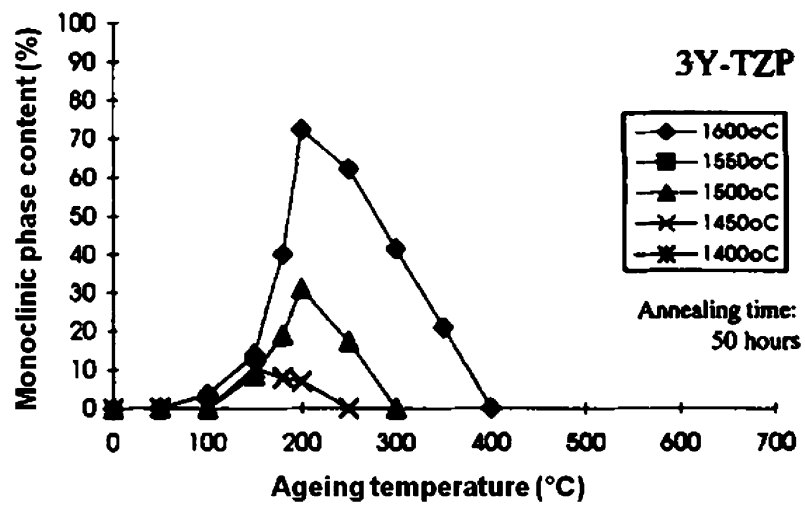

Fig. 2. The level of surface monoclinic phase and the ageing temperature of $3 \mathrm{Y}-\mathrm{TZP}\left(97 \mathrm{~mol} \% \mathrm{ZrO}_{2}, 3 \mathrm{~mol} \% \mathrm{Y}_{2} \mathrm{O}_{3}\right)$ with different sintering temperatures and aged for $50 \mathrm{~h}$ in air. ${ }^{42)}$

\subsection{Alumina-zirconia composite ceramic}

The Alumina-Zirconia composite has overcome the limitations of Alumina low toughness and Zirconia ageing effects. Moreover, Alumina-Zirconia composition exhibits better mechanical property such as higher hardness (achieve from Alumina) and toughness (supported by Zirconia). A good example of AluminaZirconia is the AMC (named BIOLOX ${ }^{\circledR}$ Delta) which consists of 80 vol. $\% \mathrm{Al}_{2} \mathrm{O}_{3}, 18.5$ vol. $\% \mathrm{ZrO}_{2}$ and 1.5 vol.\% of mixed oxides $\left(\mathrm{CrO}_{2}, \mathrm{Y}_{2} \mathrm{O}_{3}\right.$ and $\left.\mathrm{SrO}\right)$. Recently, Askari et al. $\left.{ }^{43}\right)$ reported that a functionally graded material (FGM) built with $\mathrm{Al}_{2} \mathrm{O}_{3} / \mathrm{SiC} / \mathrm{ZrO}_{2}$ has excellent mechanical property: the outer layers exhibited higher hardness $(20.8 \pm 0.3 \mathrm{GPa})$ due to presence of $\mathrm{SiC}$, while the inner layers were relatively consisted of low hardness due to $\mathrm{ZrO}_{2}$ presence. However, the fracture toughness was found to be as high as 7 to $8 \mathrm{MPam}^{1 / 2}$ at the inner layer which is similar to natural bone $\left(2-12 \mathrm{MPam}^{1 / 2}\right)$. Hydroxyapatite-Alumina-Zirconia (HAp- $\mathrm{Al}_{2} \mathrm{O}_{3}-\mathrm{YSZ}$ ) FGM is another form of Alumina-Zirconia biocomposite which does not only hold superior physical properties but also have higher influence on cell adhesion. ${ }^{44)}$

\subsection{Alumina-zirconia FGM CoC hip joints}

Pure Alumina Oxide $\left(\mathrm{Al}_{2} \mathrm{O}_{3}\right)$ hip joints were found to be biocompatible and highly wear-resistant material. However, these hip joints suffered from a risk of brittleness due to its limited fracture toughness. Apart of that, $\mathrm{ZrO}_{2}$ THRs were found to have higher wear rates than Alumina $\left(\mathrm{Al}_{2} \mathrm{O}_{3}\right) \mathrm{CoC}$ THR. Particularly, Alumina-Zirconia functional graded material improves tribological properties and maintains a combination of hardness and fracture toughness which is comparable to healthy bone. ${ }^{43)} \mathrm{A}$ few studies of Zirconia wear was done in water surrounding had concluded that Y-TZP materials might indicate mechanical strength degradation under such environments. ${ }^{15)}$ Zirconia possibly encountered transformation phase that changed its mechanical and tribology properties. In different tests that used a alumina-onzirconia bearing, the wear rate was low, but the wear particles produce by micro-cracking indicated that the use of Zirconia as bearing couple is still a risk. ${ }^{45)}$ By having gradual layer of Alumina and Zirconia composition, this will offer a tough and compression resistance of Zirconia core through to a hard and scratch resistant surface layer of Alumina which then provide a distinctive combination of properties. The enhanced properties of such a functionally graded material depends essentially on productively shaping and sintering, and eluding effects associated with the difference sintering of both materials. The lower shrinkage of Alumina compared to Zirconia, as well as the deviation of the coefficients of thermal expansion, may result in exceptional stresses within the gradual composite. At the same time, this gives a certain possibility to crack formation but on the other hand, a worthwhile effect on the wear activities due to the compressive stresses in the Alumina surface layer can be expected. Therefore, a right stress balance along the graded Alumina-Zirconia is required to beneficially affect the total performance of the implant.

\section{Discussion}

\subsection{Concern regarding of ceramic bearing THR}

Reliability of ceramic as bearing couple for THR has been an issue since its emergence as alternative materials in 1970. Among all other clinical issues related to ceramics bearing, three had been identified, that need to be deal with before using ceramics as bearing couple; ball head fracture, impingement and feasible of revision after a failed $\mathrm{CoC}$ THR. ${ }^{4}$ ) Fracture remains a concern with ceramic load bearing. Both Alumina and Zirconia ceramics implant are known to be brittle materials and could fracture in vivo as latter demonstrates high fracture toughness values, but lower than those of the metals used in surface bearing. The fracture toughness $\left(\mathrm{K}_{1} \mathrm{c}\right)$ is the response of brittleness in ceramic materials. Fracture will happen whenever the stress-intensity factor $\left(K_{1}\right)$ of the materials exceeds the $K_{1} c$ limit. The level of fracture typically is associated to sub-critical crack growth. This is caused by flaws in the materials including pores inhomogeneities, scratches, and micronotches in the material or at its surface. ${ }^{7), 46)}$ The cracks will grow at different speed depending on the size of the initial flaw and the quality of the Alumina material. Velocity of crack growth is also assisted by the load applied from the increased body weight and high level of lifestyle activity ${ }^{46)}$ but the most significant is definitely material characteristic. Early ceramics exhibited large grained microstructure and low density which present inferior mechanical strength of the ceramic. Also, due to long sintering times, the first generation ceramics could not be developed to full density which resulted in large crystal sizes $^{5)}$ and from 1970 to late 1980 s, the fracture rate of ceramic bearing THR had been recorded as high as $13.4 \%$. ${ }^{9}$ Albeit the material properties, manufacturing and the test method for quality control of ceramics has been improved drastically, the statistic of fracture for a ceramic bearing component still occurs and would undoubtedly never be totally excluded. The basis for fractureresistant ceramics is to have very fine ceramic particles of known size, shape and structure that can flawlessly fit together to achieve an optimum packing density and this still unsettled. It is important to point out that the breakage of ceramic liner was not exactly linked to direct impact on hip during a fall or trauma. This is factual after a recent study ${ }^{47)}$ had found that even after 20 impacts at $12 \mathrm{kN}$, no ceramics liner fractured. It appears that, any assessment in the processing route or design of a well-functioning implant must be taken carefully beforehand. Slight modifications in the design of the acetabular liner could lead to increase in the possibility of fracture. ${ }^{12)}$ Surface and internal stresses that are linked to the geometry, profile and design of the prostheses can be calculated entirely and therefore predicted using a finite element analysis model. It is impossible to avoid small imperfections during material process but to reduce cracks, the initial crack length must be smaller than $100 \mu \mathrm{m} .{ }^{46)}$

\subsection{Tribological properties}

Tribology, or the science of interacting surfaces in relative motion, concerns in vitro and in vivo studies. In vivo study is a direct and valuable measurement of gaining information on the effectiveness of the long term bearing couples for hip prostheses. 
On the other hand, these investigates are relying on the analysis of failure prostheses and basically overlooking the successful implants. Moreover, the number of in vivo samples is restricted and the criterion of each design, material and size of hip implant is different in each researcher and therefore is not so useful to acknowledge new materials. For that reason, in vitro studies are usually performed as a complement and comparison to in vivo experiences but expectation of in vitro results to in vivo behavior must be done without prejudiced.

\subsection{Experimental studies of $\mathrm{Al}_{2} \mathrm{O}_{3}$ hip prosthesis}

Several in vitro wear studies had claimed that Alumina $\mathrm{CoC}$ is one of the excellent bearing combinations. ${ }^{7), 48)}$ The outstanding tribologic characteristic of the Alumina $\mathrm{CoC}$ are linked to a small surface roughness because of the small grain size and proper manufacturing process resulting in a high hardness contributed mainly to high scratch resistance, a low wetting angle, and a good fluid-film lubrication. ${ }^{46)}$ In vitro wear testing of Alumina $\mathrm{CoC}$ showed two phases of wear rates. The first phase is run-in phase which concerns the first million cycles during which volumetric wear rate measures 0.1 to $0.2 \mathrm{~mm}^{3}$. During the second phase, or steady-state phase, volumetric wear rate decreases at less than $0.01 \mathrm{~mm}^{3}$ per million cycles. ${ }^{46)}$ In an in vivo study, Clark et al. had found that Alumina liners wore at steady-state phase of $0.004 \mathrm{~mm}^{3}$ per million cycles; 5000 times less wear rate compared to metal-on-polyethylene bearing couple. ${ }^{49)}$ This results were comparable after Cohn et al. ${ }^{50)}$ run in vitro experiment. They found that Alumina $\mathrm{CoC}$ bearings produce 0.2 billion wear particles/year, which was 3000 times ( 0.6 trillion wear particles/ year) lesser wear rate than metal-on-polyethylene bearings, and the wear debris of the ceramics were small. In another experimental study on $28-\mathrm{mm}$ femoral heads, Oonishi et al. ${ }^{51}$ had calculated the mean wear of Alumina $\mathrm{CoC}$ was about $1.2 \mathrm{~mm}^{3}$ per million cycles during the run-in period and $0.02 \mathrm{~mm}^{3}$ per million cycles during the steady-state phase. Laboratory wear studies of zirconia-on-zirconia articulation have been uneven. Recently, in a study to compare the polyethylene wear and prevalence of periprosthetic osteolysis in THRs performed using a $28-\mathrm{mm}$ Zirconia against a $28-\mathrm{mm}$ Cobalt Chromium femoral ball head, Cohn et al. ${ }^{50)}$ found that the wear rate were $0.11 \mathrm{~mm} /$ year for the cobalt chromium and $0.14 \mathrm{~mm} /$ year in Zirconia femoral ball heads. They concluded that there was no different in wear rates in THRs between the metal and zirconia femoral ball heads which contradict the purpose of the ceramic itself. Whereas others have demonstrated excellent wear resistance. ${ }^{52), 53)}$

\subsection{In vivo wear studies-retrieved implants}

Besides in vitro wear studies, comprehensive retrieval studies have been done to better understand failures and to avoid them in the future. ${ }^{4)}$ The wear patterns and mapping of a series of explanted Alumina components retrieved for aseptic loosening of the socket were investigated recently. ${ }^{54), 55)}$ Prudhommeaux et al. had performed wear quantification on macroscopic and microscopic scales in combination with microstructure analysis, clinical data, and roentgenographic data to identify the main risk factors that involved in the in vivo Alumina wear process. ${ }^{54}$ ) During the 11-year follow-up study, there was eleven Alumina THRs reported to have aseptic loosening. They used coordinate measuring machine to examine the macroscopic wear, Talysurf analysis to evaluate the microscopic wear elements and Scanning Electron Microscopy was used to analyze the Alumina microstructures. From the 11 available components, two had shown evidence of massive wear. The remaining nine pairs exhibited linear wear rates lower than $15 \mu \mathrm{m} /$ year. Published Alumina wear rates measured in vivo seemed to be inconsistent. Boutin et al. ${ }^{56)}$ stated that wear rates varying from 5 to $9 \mu \mathrm{m} /$ year whereas Mittelmeier and Heisel ${ }^{57)}$ reported a wear rate of around $10 \mu \mathrm{m} /$ year.

\section{Conclusion}

The objective of this review is to bring issues and information about Alumina, Zirconia and Alumina-Zirconia composite as ceramic-on-ceramic hip joints. No material is flawless that can match human hip joint except the bone itself. Nevertheless, compared with metal biomaterials, nanocomposites ceramic with an appropriate composition of Alumina and Zirconia are better in enduring the rigorous environment of human hip articulation. The new ceramic composites is very promising materials in the fabrication of long lasting total hip joint replacements as this composite exhibit mechanical and tribology tolerance such as high toughness, high hardness, low wear rate, small wear debris, high thermal efficiency, and good surface to surface lubrications. Researchers and biomedical engineers around the world are striving to develop an ideal load bearing, in which one day patients with hip problem would live using artificial hip joint that can last more than 40 years and that could be superior for young patients with their active lifestyle.

Acknowledgement This study was supported by UM/MOHE/ HIR Project No. D000010-16001.

\section{References}

1) J. M. Wilkinson, N. F. Peel, R. A. Elson, I. Stockley and R. Eastell, J. Bone Joint Surg. Br., 83, 283-288 (2001).

2) B. Masson, Int. Orthop., 33, 359-363 (2009).

3) P. Boutin, Clin. Orthop. Relat. Res., 379, 3-11 (2000).

4) R. Nizard, L. Sedel, D. Hannouche, M. Hamadouche and P. Bizot, J. Bone Joint Surg. Br., 87, 755-758 (2005).

5) P. Zeng, Mater. Sci. Technol., 24, 505-516 (2008).

6) J. E. Nevelos, F. Prudhommeaux, M. Hamadouche, C. Doyle, E. Ingham, A. Meunier, A. B. Nevelos, L. Sedel and J. Fisher, J. Bone Joint Surg. Br., 83, 598-603 (2001).

7) D. Hannouche, A. Zaoui, F. Zadegan, L. Sedel and R. Nizard, Int. Orthop., 35, 207-213 (2011).

8) W. N. Capello, J. A. Dantonio, J. R. Feinberg and M. T. Manley, Instr. Course Lect., 54, 171-176 (2005).

9) G. Willmann, Clin. Orthop. Relat. Res., 379, 22-28 (2000).

10) R. Murali, S. F. Bonar, G. Kirsh, W. K. Walter and W. L. Walter, J. Arthroplasty, 23, 1240.e13-e19 (2008).

11) S. B. Murphy, T. M. Ecker and M. Tannast, Clin. Orthop. Relat. Res., 453, 97-102 (2006).

12) D. Hannouche, C. Nich, P. Bizot, A. Meunier, R. Nizard and L. Sedel, Clin. Orthop. Relat. Res., 417, 19-26 (2003).

13) R. Huet, A. Sakona and S. M. Kurtz, J. Mech. Behav. Biomed. Mater., 4, 476-483 (2011).

14) W. Rieger, "Ceramic in orthopaedics", Ed. by C. B. Rieker, S. Oberholzer and U. Wyss, Hans Huber, Bern (2001) pp. 283294.

15) B. E. Bierbaum, J. Nairus, D. Kuesis, J. C. Morrison and D. Ward, Clin. Orthop. Relat. Res., 405, 158-163 (2002).

16) P. Boyer, D. Huten, P. Loriaut, V. Lestrat, C. Jeanrot and P. Massin, Orthop. Traumatol. Surg. Res., 96, 616-622 (2010).

17) Z. Bascarevic, Z. Vukasinovic, N. Slavkovic, B. Dulic, G. Trajkovic, V. Bascarevic and S. Timotijevic, Int. Orthop., 34, 1129-1135 (2010)

18) I. Y. Choi, Y. S. Kim, K. T. Hwang and Y. H. Kim, Clin. Orthop. Relat. Res., 468, 3234-3239 (2010).

19) G. E. Petsatodis, P. P. Papadopoulos, K. A. Papavasiliou, I. G. Hatzokos, F. G. Agathangelidis and A. G. Christodoulou, 
J. Bone Jt. Surg., Am. Vol. (CD-ROM. Ed.), 92, 639-644 (2010).

20) P. Christel, A. Meunier, M. Heller, J. Torre and C. Peillle, J. Biomed. Mater. Res., 23, 45-61 (1989).

21) C. Piconi, W. Burger, H. g. Richter, A. Cittadini, G. Maccauro and V. Covacci, Biomaterials, 19, 1489-1494 (1998).

22) V. Covacci, N. Bruzzese, G. Maccauro, C. Andreassi, G. Ricci and C. Piconi, Biomaterials, 20, 371-376 (1999).

23) V. Silva, F. Lameiras and Z. Lobato, J. Biomed. Mater. Res., 63, 583-590 (2002).

24) I. Dion, L. Bordenave and F. Levebre, J. Mater. Sci.: Mater. Med., 5, 18-24 (1994).

25) P. Torricelli, E. Verne, C. Brovarone, P. Appendino, F. Rustichelli and A. Krajewski, Biomaterials, 22, 2535-2543 (2001).

26) C. Lohmann, D. Dean, G. Koster, D. Casasola, G. Buchhorn and U. Fink, Biomaterials, 23, 1855-1863 (2002).

27) B. Cales and Y. Stefani, J. Mater. Sci.: Mater. Med., 5, 376-380 (1994).

28) B. Cales, Clin. Orthop. Relat. Res., 379, 94-112 (2000).

29) L. F. Blaise, Villermaux and B. Cales, Key Eng. Mater., 192, 553-556 (2001).

30) P. Maury, E. Gagneux, F. Gautier and S. Didelot, Proc. 5th Symp. on The Ceramics Technologhy, Thieme Medical Publishers (2000) pp. 16-18.

31) P. Christel, Bull. Hosp. Jt. Dis. Orthop. Inst., 49, 170-177 (1989).

32) R. Garvie and P. Nicholson, J. Am. Ceram. Soc., 55, 152-157 (1972).

33) K. Tsukuma, Y. Kubota and T. Tsukidate, "Advances in Ceramics", Ed. by N. Claussen, M. Ruhle and A. H. Heuer, The American Ceramic Society, Inc.: Columbus, Ohio (1984) pp. 382-390.

34) M. Watanabe, S. Iio and I. Fukuura, "Advances in Ceramics", Ed. by N. Claussen, M. Ruhle and A. H. Heuer, The American Ceramic Society, Inc: Columbus, Ohio (1984) pp. 391-398.

35) A. J. A. Winnubst and A. J. Burggraaf, "Advances in Ceramics", Ed. by S. Somiya, N. Yamamoto and H. Yanagida, The American Ceramic Society, Inc: Columbus, Ohio (1988) pp. $39-48$.

36) I. C. Clarke, M. Manaka, D. D. Green, P. Williams, G. Pezzotii, Y. H. Kim, M. Ides, N. Sugano, L. Sedel, C. Delauney, B. Ben Nissan, T. Donaldson and G. A. Gustafson, J. Bone Jt. Surg., Am. Vol. (CD-ROM. Ed.), 85, 73-84 (2003).

37) M. Slonaker and T. Goswami, Mater. Des., 25, 94-105 (2004).

38) K. Shimizu, M. Oka, P. Kumar, Y. Kotoura, T. Yamamuro, K. Makinouchi and T. Nakamura, J. Biomed. Mater. Res., 27,
729-734 (1993).

39) H. G. Richter, W. Burger and F. Osthues, "Bioceramics", Ed. by G. H. Anderson and A. YIi-Urpo, ButterworthHeinmann: London (1994) pp. 401-406.

40) I. C. Clarke, D. D. Green, G. Pezzotti and D. Donaldson, "Bioceramic and Other Alternative Bearings in Total Joint Replacement: the 10th BIOLOX ${ }^{\circledR}$ Symposium", Steinkopff, Washington D.C. (2005).

41) S. Lawson, J. Eur. Ceram. Soc., 15, 485-502 (1995).

42) T. Sato and M. Shimada, J. Am. Ceram. Soc., 68, 356-359 (1985).

43) E. Askari, M. Mehrali, I. H. Metselaar, N. A. Kadri and M. M. Rahman, J. Mech. Behav. Biomed. Mater, 12, 144-150 (2012).

44) M. A. F. Afzal, P. Kesarwani, K. M. Reddy, S. Kalmodia, B. Basu and K. Balani, Mater. Sci. Eng., 32, 1164-1173 (2012).

45) S. Deville, J. Chevalier and L. Gremillard, Biomaterials, 27, 2186-2192 (2006).

46) D. Hannouche, M. Hamadouche, R. Nizard, P. Bizot, A. Meunier and L. Sedel, Clin. Orthop. Relat. Res., 430, 62-71 (2005).

47) S. A. Maher, J. D. Lipman, L. J. Curley, M. Gilchrist and T. M. Wright, J. Arthroplasty, 18, 936-941 (2003).

48) J. L. Tipper, A. Hatton, J. E. Nevelos, E. Ingham, C. Doyle, R. Streicher, A. B. Nevelos and J. Fisher, Biomaterials, 23, 34413448 (2002).

49) I. C. Clarke, V. Good, P. Williams, D. Schroeder, L. Anissian, A. Stark, H. Oonishi, J. Schuldies and G. Gustafson, Proc. Inst. Mech. Eng., Part H., 214, 331-347 (2000).

50) R. M. Cohn, A. Gonzalez Della Valle, M. Peterson and C. N. Cornell, J. Hospital for Special Surgery, 4, 107-111 (2008).

51) H. Oonishi, I. C. Clarke, V. Good, H. Amino and M. Ueno, J. Biomed. Mater. Res., Part A, 70, 523-532 (2004).

52) F. Villermaux, L. Biaise, B. Cales and J. M. Drouin, Proc. 25th Ann. Mtg. Bio. Mat. Soc., (1999) pp. 135.

53) I. C. Clarke, V. Good, K. Yamamoto, D. Schroeder and A. Gustafson, Transactions of the Sixth World Biomaterials Congress, Minneapolis, U.S.A. (2000).

54) F. Prudhommeaux, M. Hamadouche, J. Nevelos, C. Doyle, A. Meunier and L. Sedel, Clin. Orthop. Relat. Res., 379, 113-122 (2000).

55) T. Shishido, K. Yamamoto, S. Tanaka, T. Masaoka, I. C. Clarke and P. Williams, J. Arthroplasty, 21, 294-298 (2006).

56) P. Boutin, P. Christel, J. M. Dorlot, A. Meunier, A. de Roquancourt, D. Blanquaert, S. Herman, L. Sedel and J. Witvoet, J. Biomed. Mater. Res., 22, 1203-1232 (1988).

57) H. Mittelmeier and J. Heisel, Clin. Orthop. Relat. Res., 282, 64-72 (1992) 